\title{
Hydrogeological Characteristics of Groundwater Yield in Shallow Wells of the Regolith Aquifer: a Study from Ilorin, Nigeria
}

Ifabiyi, I.P., Ashaolu, E.D and Omotosho, O*

Department of Geography and Environmental Management, Faculty of Social Sciences, University of Ilorin, PMB 1515, Ilorin, Nigeria (*oluomotoshor@gmail.com).

\begin{abstract}
Present paper tries to understand the influence of hydrogeological characteristics on groundwater yield of shallow wells in regolith aquifer, Ilorin, Nigeria. The data on hydrogeological characteristics such as drawdown, water level, depth of borehole, depth of overburden and well yield for 78 borewells were collected from Kwara State Ministry of Water Resources and Lower Niger River Basin Development Authority in Ilorin. While the aquifer transmissivity and well specific capacity was calculated from this data. The data obtained were subjected to Pearson moment correlation, multiple and stepwise multiple regression analysis. The results of the stepwise multiple regression $\left(\mathrm{R}^{2}\right.$ of .929$)$ indicates that aquifer transmissivity and drawdown contributed $92.9 \%$ to the variability in well yield in the study area. It is concluded that while constructing wells, aquifer transmissivity and the rate of drawdown be taking into account for the purpose of having productive well in the study area.
\end{abstract}

Keywords: Aquifer Transmissivity, Well Specific Capacity, Regolith Aquifer, Drawdown, Well Yield, Groundwater, Ilorin, Nigeria.

\section{INTRODUCTION}

Groundwater is considered as the world's largest accessible store of freshwater, considered as a logical resource to turn to when confronted by water shortages which is often associated with low and variable river discharges (Goulden et al., 2009; Kundzewiez and Dou, 2009; Taylor et al., 2009). Groundwater is often of potable quality and does not require expensive treatments and permits scaled development (upon demand) using infrastructure that is normally of lower cost relative to surface water feed supplies (Taylor et al., 2009). Groundwater occurrence in any region of the world is largely dependent on the nature and type of the aquifer. Ilorin is underlain by Precambrian Basement Complex; comprising mostly of gneiss, granite, schist, undifferentiated meta-sediments rocks and overburden that are composed mainly of clay, sand and silt soils (Ifabiyi and Ashaolu, 2013). The aquifers of the Basement Complex rocks are the regolith and the fractures in the fresh bedrock (Bala et al., 2011).

According to Wright (1992), the regolith aquifers occur more extensively in areas where a relatively thick and permeable saturated rock layers exist which is able to meet the demands 
required, usually of a hand-pump installation. Based on Wright's submission, regolith aquifer can however be a locally significant aquifer that yields groundwater relatively easily and inexpensive to exploit. Wright (1992) reported that in regions of moderate to high annual rainfall, where rainfall is greater than $600 \mathrm{~mm}$ per annum, the water table occurs typically at shallow levels, which is less than 10 to $15 \mathrm{~m}$. Consequently, it is the regolith aquifer that provides the main storage and transmissivity for hand dug wells and borewells (Wright, 1992). In line with this submission, regolith aquifer can provide the main storage and transmissivity for hand dug wells and borewells in many part of the Basement Complex where annual rainfall is about $1200 \mathrm{~mm}$.

Ilorin is one of the fastest growing urban centers in Nigeria. The National population commission (2010) put the growth rate of Ilorin at $2.96 \%$ of the national growth rate. This is evident in the rate at which new residential areas or sites have been springing up in the last decade. As the population is growing, demand for water is also increasing. Studies have reported that water supply in Ilorin is unreliable and erratic (Ifabiyi and Ahmed, 2011), about 62.9\% of the population had access to pipe borne water (Aderibigbe et al., 2008). Ifabiyi and Ashaolu (2013) reported that the coverage of public water supply in Ilorin is limited to some area while others lack access to this service. Based on all these evidences, greater portion of the city rely more on groundwater (shallow and deep) to meet their domestic water needs since groundwater is often potable at source and does not require heavy investment.

Many studies were undertaken to predict the influence of hydraulic and hydrogeological characteristics on well yield in Nigeria. For example, Ifabiyi (1999) predicted the yield of boreholes in the Basement Complex rocks and sedimentary rock in the central Nigeria. The study concluded that boreholes yield is low in the Basement aquifer compared to sedimentary rock aquifer. Ifabiyi (2005) in a study of regolith aquifer in the Basement Complex of Osun basin reported well hydraulic index as the most important variable affecting well yield. Ashaolu and Adebayo (2014) discovered that $93.1 \%$ of the variation in hand dug well yield in the overburden aquifer of the Basement Complex rocks of Ilara-Mokin, southwestern Nigeria can be explained by well depth, depth to water, depth of water and well diameter.

From the foregoing, it has been discovered that explanation of results from previous studies may not be acceptable in all Basement Complex rocks aquifer, in view of the extent of variability which exist in the basin of decomposition in hard rocks (Azeez, 1972). However, the focus of the (C) CNCS, Mekelle University 
paper is to determine the hydrogeological characteristics of groundwater yield in wells of the regolith aquifer in the Basement Complex rocks in Ilorin, Nigeria.

\subsection{Study Area}

Ilorin the Kwara state capital is located on latitude $08^{\circ} 32^{\prime}$ north and longitude $04^{\circ} 33^{\prime}$ east. It is one of the fastest growing urban centers in Nigeria. There has been a huge increase in the population of Ilorin since it became the state capital in 1976. The population growth rate is much higher than other cities at 2.5 percent of the national growth. The 2006 census put the population of Ilorin city to about 847,582 (NPC, 2006 provisional results). The landscape ranges in elevation in the western part from $273 \mathrm{~m}$ to $333 \mathrm{~m}$ and in the eastern part from $273 \mathrm{~m}$ to $364 \mathrm{~m}$. Sobi hill is the dominant landform, it is an inselberg, and it is the highest point in the city (394 m above sea level.) Ilorin has a tropical wet and dry climate. Wet season is experienced from May to November and dry season from November to March. Rainfall condition in Ilorin exhibits greater variability both temporarily and spatial. The annual mean rainfall is about $1,200 \mathrm{~mm}$, exhibiting the double maximal pattern between April and October of every year. Relative humidity varies seasonally with an average of $79.7 \%$.

The city is underlain by Precambrian Basement Complex; comprising mostly gneiss, granite, schist, undifferentiated metasediment rocks and overburden that are composed mainly of clay, sand and silt soils. The underlying Precambrian igneous and metamorphic rocks of Basement Complex are neither porous nor permeable except in places where they are deeply weathered or have weak zones, and the presence of local structures such as faults, fractures joints and shears (Azeez, 1972). Some part of the town is also laid by sedimentary rocks, which contains both primary and secondary laterites and alluvial deposits. Groundwater in the alluvium is recharged directly by rainfall or the adjoining overflowing river system. In the dry season, the alluvium sustains considerable subsurface groundwater flow. The alluvial deposits have been exploited, with successful wells and boreholes in Ilorin metropolis and its surroundings. Ilorin is located on a Basement Complex rock which is of regolith aquifer. This makes most of the shallow wells in this area to be seasonal in nature and some of the wells (borewell) also failing especially during the dry season. This may be attributed to the hydrogeological characteristics of the groundwater resources and to the thickness of the regolith which is thin in this area. The drainage system of Ilorin is dendritic in nature, and is dominated by Asa River, which flows from south to north and divides the city into two parts, the western and eastern parts. The western part represents the (C) CNCS, Mekelle University 
indigenous area. The eastern part coincides with the modern layout. Major rivers draining the city are: Asa, Agba, Alalubosa, Okun, Osere, Aluko. The geology map of the study area showing the sampled point is presented in figure 1 .

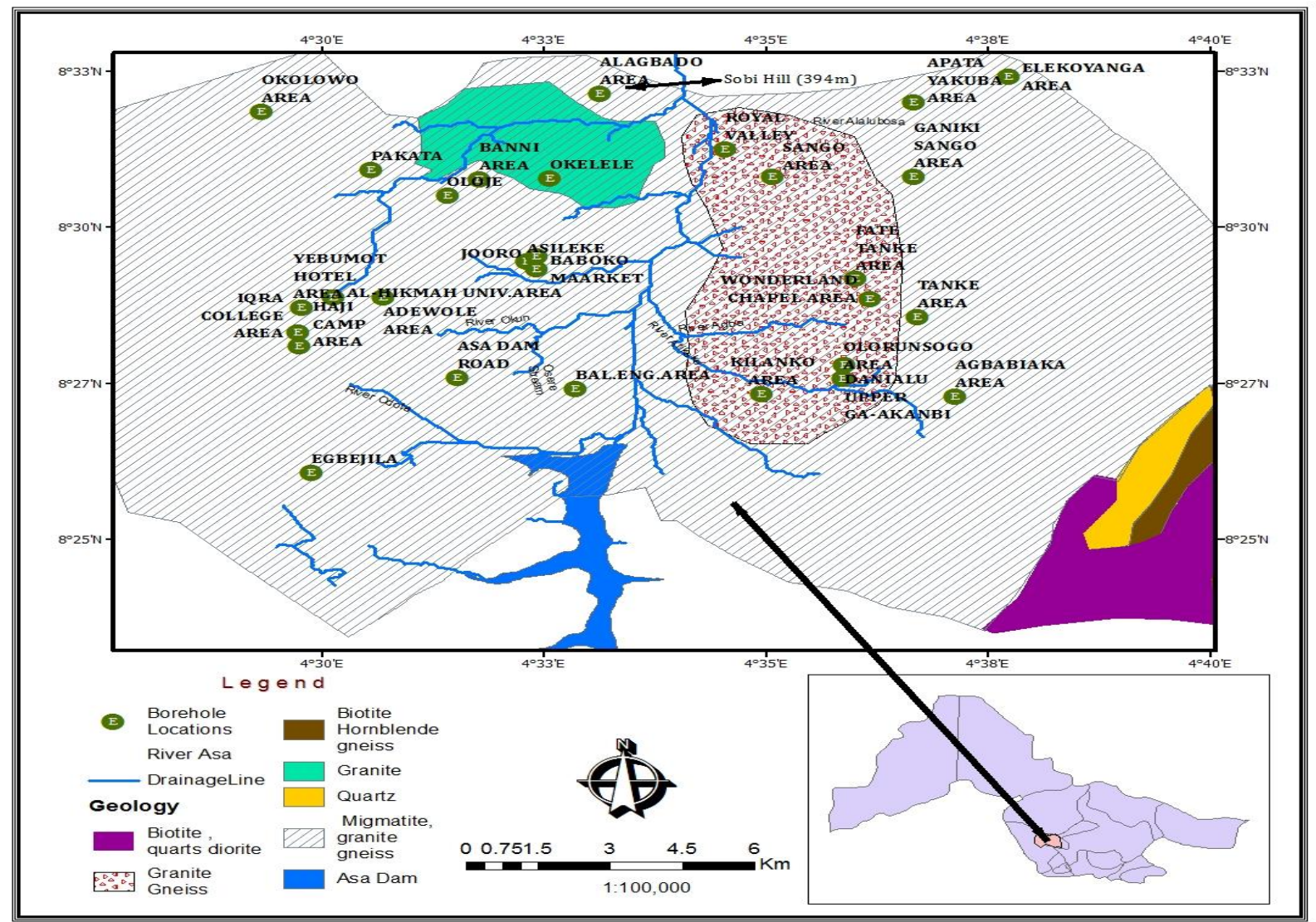

Figure 1. Geological map of Ilorin showing some of the sampled points.

\section{Material and Methods}

\subsection{Data Collection}

The data used in this paper include well yield or pump rate, depth of well, drawdown, water level, depth or thickness of overburden, aquifer transmissivity and well specific capacity. These data were collected from Kwara State Ministry of Water Resources and Lower Niger River Basin Development Authority, Ilorin. The data however, does not have coordinates, which made the researchers to embark on field work to identify and take coordinates of the borewells using the address tags given to them by the two organizations. A total number of 100 borewells points with their respective pumping test data were collected. The coordinates of these borewells were imported into ArcGis 10.2 and overlain on the geological map of the study area to enhance the 
choice of borewells locations to be selected for the study. At the end, it was only 78 borewells that spread across the study area which gave a true representation of the underlying geology that were considered and used for analysis.

\subsection{Data Analysis}

The following methods were used to analyze the data:

1) Descriptive statistics such as mean was used to summarize the data and get the mean value for each hydrogeological variables in the study area, standard deviation was used to determine the absolute deviation from the mean and coefficient of variation was used to determine the relative variation of the data set from the mean.

2) The well specific capacity which is a function of the aquifer was calculated by dividing discharge rate by drawdown of the pumping well. Transmissivity was determined based on Logan (1964) estimation for phreatic aquifers as shown in equation 1:

$T=a \times(Q / s)$

Where $\mathbf{T}$ the aquifer transmissivity $(\mathrm{m} 2 / \mathrm{d}), \mathbf{a}$ is the dimensional constant $=1.22, \mathbf{Q}$ is well yield $(\mathrm{m} 3 / \mathrm{d})$, and $\mathbf{s}$ is drawdown $(\mathrm{m})$.

3) The association between hydrogeological characteristics and wells yield in the study area is determined with the use of Pearson Moment Correlation Coefficients. The equation is as shown in equation 2.

$$
r=\frac{\sum(x-\bar{x})(y-\bar{y})}{\sqrt{\sum(x-\bar{x})^{2} \sum(y-\bar{y})^{2}}}
$$

$\mathbf{r}$ is the Product Moment Correlation, $\mathbf{y}$ is the groundwater yield, and $\mathbf{x}$ is the hydrogeological characteristics.

4) The influence of hydrogeological characteristics on well yield in the study area was determined by using multiple linear (enter and stepwise) regression analysis. The use of stepwise regression assisted us to know the most important hydrogeological characteristics contributing to well yield in the study area. The equation is as shown in equation 3 .

$y=a+b_{1} x_{1}+b_{2} x_{2} \ldots b_{n} x_{n}+e$

Where $\mathbf{y}=$ well yield; $\mathrm{a}=$ intercept; $\mathrm{e}=$ error term

$\mathbf{b}_{\mathbf{1}}-\mathbf{b}_{\mathbf{n}}=$ partial regression coefficient of the hydrogeological characteristics variables; $\mathbf{x}_{\mathbf{1}}-\mathbf{x}_{\mathbf{n}}=$ hydrogeological characteristics variables. 
Ifabiyi (2005), Ashaolu and Adebayo (2014) used this method to determine influence of hydrogeological and well parameters on groundwater yield.

\section{RESULTS}

\subsection{Descriptive Analysis of Borewell Yield and Hydrogeological Characteristics}

In Table 1, the mean well yield is 1.35 liters/sec with a standard deviation of 0.52 liters/sec and coefficient of variation of $38.52 \%$. The mean water level is $31.36 \mathrm{~m}$ with a standard deviation of $3.95 \mathrm{~m}$ and coefficient of variation of $12.60 \%$.Figure 2 , shows a typical hand-pump bore-well and water containers queue in the study area. The pump handle was padlock after the water level has dropped, to allow the water level in the well to recover. This is because more energy and time is usually expended in pumping the water, whenever it has dropped considerably. The mean aquifer transmissivity is $0.09 \mathrm{~m}^{2} / \mathrm{d}$ with a standard deviation of $0.03 \mathrm{~m}^{2} / \mathrm{d}$ and coefficient of variation of $33.33 \%$.The mean well specific capacity is $0.20 \mathrm{~m}^{2} /$ day with a standard deviation of $0.19 \mathrm{~m}^{2} /$ day and the coefficient of variation is $95.00 \%$.

Table 1. Descriptive statistic of well yield and hydrogeological characteristics.

\begin{tabular}{|c|c|c|c|c|c|c|}
\hline S.No & Parameters & Minimum & Maximum & Mean & $\begin{array}{l}\text { Standard } \\
\text { Deviation }\end{array}$ & $\begin{array}{l}\text { Coefficient } \\
\text { of Variation }\end{array}$ \\
\hline 1. & Yield & 0.18 & 3.00 & 1.35 & 0.52 & $38.52 \%$ \\
\hline 2. & Water Level & 20.13 & 38.6 & 31.36 & 3.95 & $12.60 \%$ \\
\hline 3. & Aquifer Transmissivity & 0.02 & 0.19 & 0.09 & 0.03 & $33.33 \%$ \\
\hline 4. & Well Specific Capacity & 0.01 & 0.99 & 0.20 & 0.19 & $95.00 \%$ \\
\hline 5. & Borehole depth & 30.00 & 45.00 & 39.23 & 4.26 & $10.86 \%$ \\
\hline 6. & Drawdown & 11.32 & 22.63 & 18.36 & 3.55 & $19.34 \%$ \\
\hline 7. & Depth of overburden & 3.50 & 30.00 & 14.58 & 5.93 & $40.67 \%$ \\
\hline
\end{tabular}

The mean well depth is $39.23 \mathrm{~m}$ with a standard deviation of $4.26 \mathrm{~m}$ and coefficient of variation of $10.86 \%$. The mean drawdown is $18.36 \mathrm{~m}$ with a standard deviation of $3.55 \mathrm{~m}$ and coefficient of variation of $19.34 \%$. The mean depth of overburden is $14.58 \mathrm{~m}$ with a standard deviation of $5.93 \mathrm{~m}$ and coefficient of variation of $40.67 \%$. 


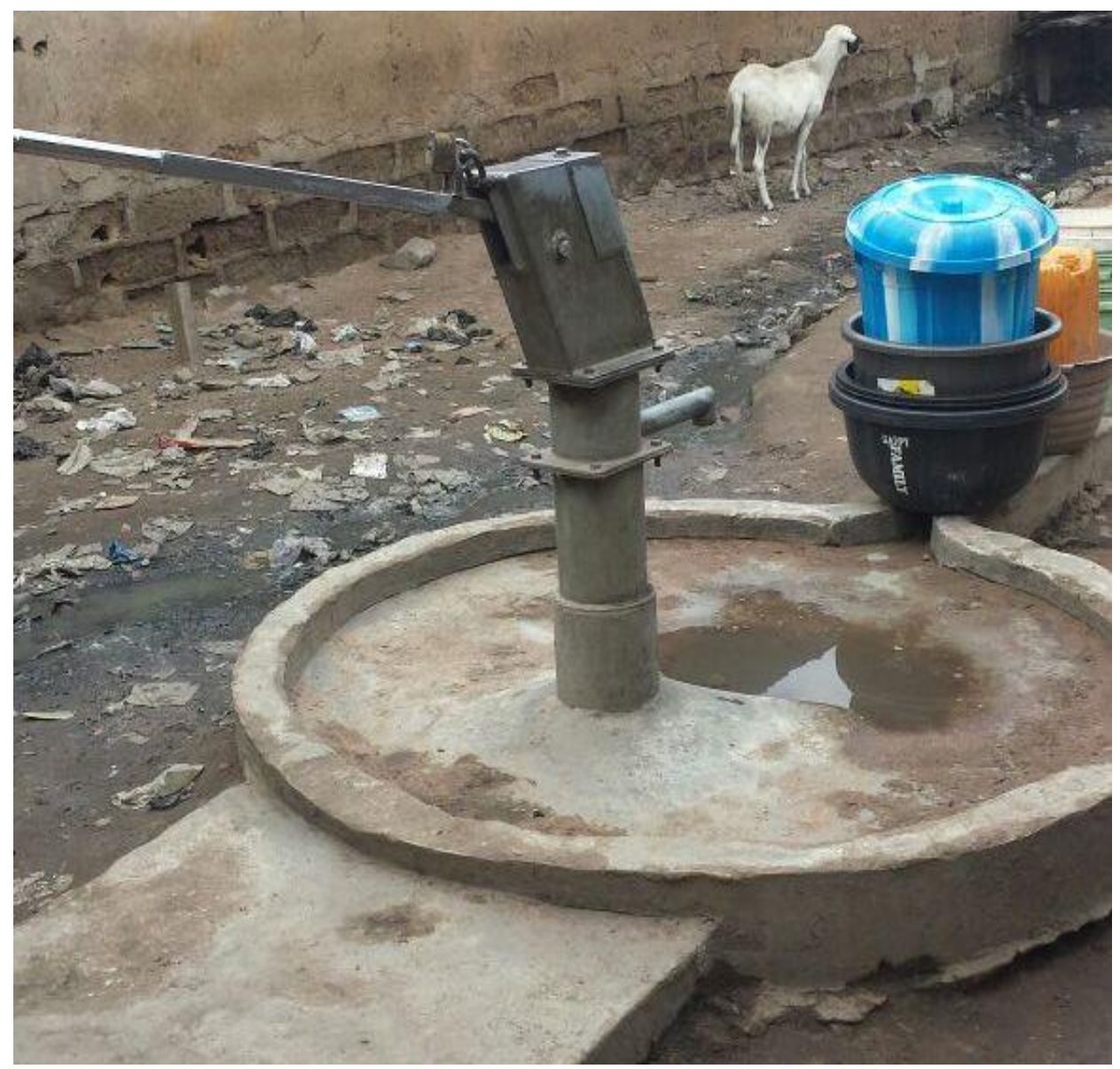

Figure 2. Hand-pump borewell in the study area.

\subsection{Association between Well Yield and Hydrogeological Characteristics}

The result of Pearson moment correlation (Table 2) shows that there existed a mild positive relationship $(\mathrm{r}=0.389)$ between well yield and water level which is statistically significant at 95\% confidence level. Well yield and aquifer transmissivity exhibit a very strong positive relationship $(\mathrm{r}=0.812)$ at $99 \%$ confidence level. Also, there is a mild positive relationship $(\mathrm{r}=$ 0.383 ) between well yield and well specific capacity at $95 \%$ confidence level. Well yield exhibit a strong positive relationship ( $\mathrm{r}=0.505)$ with well depth at $99 \%$ confidence level. Well yield further exhibit positive relationship $(\mathrm{r}=0.407)$ with drawdown which is statistically significant at $95 \%$ confidence level, and depth of overburden $(\mathrm{r}=0.29)$ which is not statistically significant. Lastly, there is a strong positive relationship $(\mathrm{r}=0.911)$ between depth of overburden and well depth at $99 \%$ confident level. 
Table 2. Association between well yield and hydrogeological characteristics

\begin{tabular}{|c|c|c|c|c|c|c|c|}
\hline S.No & & Yield & $\begin{array}{l}\text { Water } \\
\text { Level }\end{array}$ & $\begin{array}{l}\text { Aquifer } \\
\text { Transmissivity }\end{array}$ & $\begin{array}{l}\text { Well } \\
\text { Specific } \\
\text { capacity }\end{array}$ & $\begin{array}{l}\text { Well } \\
\text { depth }\end{array}$ & Drawdown \\
\hline 1. & Water Level & $.389 *$ & & & & & \\
\hline 2. & $\begin{array}{l}\text { Aquifer } \\
\text { Transmissivity }\end{array}$ & $.812 * *$ & -0.023 & & & & \\
\hline 3. & $\begin{array}{l}\text { Well Specific } \\
\text { capacity }\end{array}$ & $.383^{*}$ & 0.351 & 0.223 & & & \\
\hline 4. & Well depth & $.505 * *$ & $.775 * *$ & -0.008 & 0.213 & & \\
\hline 5. & Drawdown & $.407 *$ & $.760 * *$ & -0.133 & 0.245 & $.911 * *$ & \\
\hline 6. & $\begin{array}{l}\text { Depth of } \\
\text { overburden }\end{array}$ & 0.299 & 0.233 & -0.019 & 0.017 & $.529 * *$ & $.441^{*}$ \\
\hline
\end{tabular}

Note: **Correlation is significant at the 0.01 level (2-tailed).

*Correlation is significant at the 0.05 level (2-tailed).

\subsection{Influence of Hydrogeological Characteristics on Well Yield}

To determine the influence of hydrogeological characteristics on well yield, multiple regression analysis was carried out. The dependent variable is well yield while the independent variables are depth of overburden, well specific capacity, aquifer transmissivity, water level, drawdown and well depth. Table 3 show the results of the multiple regression analysis between well yield (dependent) and, depth of overburden, well specific capacity, aquifer transmissivity, water level, drawdown and well depth (independents). The model using enter method has an $\mathrm{R}^{2}$ of .947 , standard error of 0.13410 which indicates that the model has a very low margin of error and is statistically significant at $95 \%$ confidence level. The $\mathrm{R}^{2}$ of .947 shows that depth of overburden, well specific capacity, aquifer transmissivity, water level, drawdown and borehole depth contributed $94.7 \%$ to the variability in well yield in the study area.

Table 3. Model summary of the influence of hydrogeological characteristics on well yield.

\begin{tabular}{|lrlll|}
\hline Model & $\boldsymbol{R}$ & $\boldsymbol{R}$ Square & Adjusted R Square & Std. Error of the Estimate \\
\hline 1 & $0.973^{\mathrm{a}}$ & 0.947 & 0.933 & 0.13410 \\
\hline
\end{tabular}

a.Predictors: (Constant), Depth of overburden, Well Specific capacity, Aquifer Transmissivity, Water level, Drawdown, Well depth 
The relationship between the well yield and hydrogeological characteristic is presented in table 4 , and it shows that for every $1 \%$ increase in aquifer transmissivity, well specific capacity, well depth, drawdown and depth of overburden, there is $12.77 \% .0 .156 \%, 0.022 \%, 0.045 \%$ and $0.008 \%$ increase in well yield respectively. Also, for every $1 \%$ decrease in water level, there is $0.002 \%$ decrease in well yield.

Table 4. Relationship between hydrogeological characteristics and well yield.

\begin{tabular}{|c|c|c|c|c|c|}
\hline \multirow[t]{2}{*}{ Model } & \multicolumn{2}{|c|}{$\begin{array}{l}\text { Unstandardized } \\
\text { Coefficients }\end{array}$} & \multirow{2}{*}{$\begin{array}{r}\text { Standardized } \\
\text { Coefficients } \\
\text { Beta }\end{array}$} & \multirow[t]{2}{*}{$T$} & \multirow[t]{2}{*}{ Sig. } \\
\hline & $B$ & Std. Error & & & \\
\hline (Constant) & -1.584 & .321 & & -4.932 & .000 \\
\hline 1. Water Level & -.002 & .011 & -.014 & -.167 & .869 \\
\hline 2. Aquifer Transmissivity & 12.77 & .806 & .836 & 15.859 & .000 \\
\hline 3. Well Specific capacity & .156 & .097 & .087 & 1.608 & .122 \\
\hline 4. Well depth & .022 & .017 & .181 & 1.275 & 215 \\
\hline 5. Drawdown & .045 & .019 & .305 & 2.397 & .025 \\
\hline 6. Depth of overburden & .008 & .005 & .087 & 1.441 & .163 \\
\hline
\end{tabular}

a. Dependent Variable: Yield

Based on results in table 4, the relationship between hydrogeological characteristics and well yield can be written as shown in equation 3 .

WellYield $=-1.584-0.002_{\text {Waterlevel }}+12.77_{\text {Transmissivity }}+0.156_{\text {Specticcapacity }}+0.022_{\text {WellDeph }}+0.045_{\text {DrawDown }}+0.008_{\text {Dephlofoverburden }}$ The data was further subjected to stepwise multiple regression analysis, to identify the most important hydrogeological parameter that influence well yield and the percentage of its contribution. The result of the stepwise method presented in table 5 has an $\mathrm{R}^{2}$ of .929 , which indicates that aquifer transmissivity and drawdown combined contributed $92.9 \%$ to the variability in well yield in the study area. It has a standard error of 0.14 which is negligible and makes the model to be reliable. However, aquifer transmissivity has an $\mathrm{R}^{2}$ of .659 , which indicated that aquifer transmissivity alone contributed $65.9 \%$ out of the $92.9 \%$ (aquifer transmissivity and drawdown) to the variability in well yield in the study area.

Table 5. Stepwise model summary of the influence of hydrogeological characteristics on well yield.

\begin{tabular}{|c|c|c|c|c|}
\hline Model I & & R Square & $\begin{array}{l}\text { Adjusted } R \\
\text { Square }\end{array}$ & Std. Error of the Estimate \\
\hline 1 & $0.964^{\mathrm{a}}$ & 0.929 & 0.923 & 0.14361 \\
\hline
\end{tabular}

a. Predictors: (Constant), aquifer Transmissivity, Drawdown 
The relationship between the well yield and hydrogeological characteristic using stepwise multiple regression is presented in table 6 , this shows that for every $1 \%$ increase in aquifer transmissivity and drawdown, there is $13.47 \%$ and $0.077 \%$ increase in borehole yield in the study area.

Table 6. Relationship between hydrogeological characteristics and well yield (Stepwise).

\begin{tabular}{|c|c|c|c|c|c|}
\hline \multirow[t]{2}{*}{ Model } & \multicolumn{2}{|c|}{$\begin{array}{l}\text { Unstandardized } \\
\text { Coefficients }\end{array}$} & \multirow{2}{*}{$\begin{array}{l}\text { Standardized } \\
\text { Coefficients } \\
\text { Beta }\end{array}$} & \multirow[t]{2}{*}{$T$} & \multirow[t]{2}{*}{ Sig. } \\
\hline & $B$ & Std. Error & & & \\
\hline (Constant) & -1.291 & 167 & & -7.718 & .000 \\
\hline Aquifer Transmissivity & 13.478 & .793 & .882 & 17.003 & .000 \\
\hline Drawdown & .077 & .008 & .524 & 10.111 & .000 \\
\hline
\end{tabular}

a. Dependent Variable: Yield

From on the result in Table 6, the relationship between hydrogeological characteristics and well yield using stepwise multiple regression can be written as shown in equation 4 .

$$
\text { WellYield }=-1.291+13.47_{\text {transmissivity }}+0.077_{\text {drawdown }}
$$

\section{DISCUSSION}

The mean well yield 1.35 liters/sec with a coefficient of variation of $38.52 \%$ indicates that well yield is less variable across the study area. This can be attributed to the rate at which groundwater flow horizontally in the regolith aquifer, which is a function of the level of aquifer transmissivity in the area. The mean water level is $31.36 \mathrm{~m}$ with a coefficient of variation of $12.60 \%$, which indicates that the water level is almost uniform across the study area, which is the function of the nature of the aquifer that produced water into these wells. The mean aquifer transmissivity is $0.09 \mathrm{~m}^{2} / \mathrm{d}$ with a coefficient of variation of $33.33 \%$, which indicates that the mean transmissivity is more stable across the study area. This can be attributed to the fact that granite gneiss is the largest underlying geology of the well in this area, and hence the water bearing of such geological material tends to be less variable unless in areas that is deeply weathered. The mean well depth is $39.23 \mathrm{~m}$ with a coefficient of variation of $10.86 \%$, which indicates that well depth is almost less variable across the study area. The can be attributed to the 
nature of the Basement Complex rock geology of this area which is a hard rock, that made drillers not to go beyond a certain depth when they have drilled through the regolith.

The mean well specific capacity of $0.20 \mathrm{~m}^{2} /$ day with a coefficient of variation of $95.00 \%$, indicates that the well specific capacity is highly heterogeneous across the study area. This can however be attributed to poor well design and development. For example, well casing serves to hold up the walls of wells and provide the path for the movement of the water. This is usually done with materials (hard rocks) that will not loosen and be carried away by the inflowing water at the intake section that is uncased. However, in situations where the driller believed the underlying material is fully consolidated and not try to fill it with hard rock materials, the loose soil may slow down the yield to the well. The mean drawdown is $18.36 \mathrm{~m}$ with a coefficient of variation of $19.34 \%$, which indicates that drawdown is also less variable in the study area. The mean depth of overburden is $14.58 \mathrm{~m}$ with a coefficient of variation of $40.67 \%$, which indicates that the depth of overburden slightly varied across the study area, which can be attributed to the nature of weathering that has taken place to create the superficial layer. This result also reveal that this area is characterized by shallow aquifer that does not encourage the drilling of deep well.

The result of Pearson moment correlation (Table 2) shows that there existed a mild positive relationship $(\mathrm{r}=0.389)$ between well yield and water level which is statistically significant at 95\% confidence level. This is an indication that as water level increases, all things being equal, well yield also increases and vice versa. This is expected has the level of water in the well affects pumping, and hence the yield. Well yield and aquifer transmissivity exhibit a very strong positive relationship ( $\mathrm{r}=0.812)$ at $99 \%$ confidence level. This suggested that as aquifer transmissivity increases, well yield increases. This is also expected as the rate of horizontal flow of groundwater in a specific aquifer determines the yield of groundwater into the well, hence, the amount of water that can be pumped from the well. Also, there is a mild positive relationship ( $r=$ 0.383 ) between well yield and well specific capacity at $95 \%$ confidence level, suggesting a direct proportional relationship between them. Well yield exhibit a strong positive relationship ( $\mathrm{r}=$ 0.505 ) with well depth at $99 \%$ confidence level. Which signifies that the deeper the well, the higher the yield. This result shows that the deeper the well, the greater the regolith ability to store water. Well yield further exhibit positive relationship $(r=0.407)$ with drawdown which is statistically significant at $95 \%$ confidence level, and depth of overburden $(r=0.29)$ which is not 
statistically significant. There is a strong positive relationship $(r=0.911)$ between depth of overburden and well depth at $99 \%$ confident level. This is an indication that the deeper the overburden, the deeper the well.

The model with an $\mathrm{R}^{2}$ of .947 indicates that $94.7 \%$ of the variability in well yield in the study area can be explained by this model, that is, $94.7 \%$ of variability in well yield is determined by the six explanatory variables (depth of overburden, well specific capacity, aquifer transmissivity, water level, drawdown and well depth). Ashaolu and Adebayo (2014) discovered that 93.1\% of the variation in shallow well yield in the overburden aquifer of Ilara-Mokin and its environs in southwestern Nigeria can be explained by well depth, depth to water, depth of water and well diameter. Table 4 shows that for every $1 \%$ increase in aquifer transmissivity, specific capacity, depth, drawdown and depth of overburden, there is $12.77 \% .0 .156 \%, 0.022 \%, 0.045 \%$ and $0.008 \%$ increase in well yield respectively. These results suggested that as these hydrogeological characteristics increases, the well yield also increase. Also, for every $1 \%$ decrease in water level, there is $-0.002 \%$ decrease in well yield. This is an indication that decrease in water level has a negative influence on well yield, which can be attributed to decrease in the pumping rate of the well.

The results of stepwise multiple regression analysis, to identify the most important hydrogeological parameter that influences well yield and the percentage of its contribution, indicates that aquifer transmissivity and drawdown contributed $92.9 \%$ to the variability in well yield in the study area. The stepwise regression analysis of Ifabiyi (2005) in the regolith aquifer of Osun river basin which is also located on a Basement Complex rock revealed that well hydraulic is the most important factor affecting well yield. However, aquifer transmissivity alone contributed $65.9 \%$ to the variability in well yield in the study area. These results emphasized the importance of aquifer transmissivity in groundwater exploration and development. This is the rate at which underground water flow laterally and its' determine the rate of aquifer recovery. In a regolith aquifer on the Basement Complex rock, the rate of recovery is very low because of the nature of interconnectivity in the basement rock. The importance of aquifer transmissivity in groundwater hydrology in the development of local and regional water resources was emphasized in the study of Huang et al., (2011). The relationship between the well yield and hydrogeological characteristic using stepwise multiple regression is presented in Table 6 shows 
that for every $1 \%$ increase in aquifer transmissivity and drawdown, there is $13.47 \%$ and $0.077 \%$ increase in well yield in the study area.

\section{CONCLUSION}

Ilorin is underlain by basement rock which is a poor aquifer, except in places where there are deep weathered regoliths that can yield a sizeable amount of groundwater. The study revealed that aquifer transmissivity and drawdown are the two most important hydrogeological characteristics that influence well yield in Ilorin. It is therefore concluded that during the construction of wells, the aquifer transmissivity and drawdown should be taking into account to achieve optimal yield and performance. Also, aquifer transmissivity which contributed highest to the variability of well yield in Ilorin be given special attention when developing wells, in other to have a very high productive well.

\section{ACKNOWLEDGEMENTS}

Special thanks to the management of Kwara State Ministry of Water Resources and Lower Niger River Basin Development Authority, Ilorin for providing us with the data used for this research work.

\section{REFERENCE}

Aderibigbe, S.A., Awoyemi, A.O \& Osagbemi, G.K. 2008. Availability, Adequacy and Quality of water supply in Ilorin metropolis, Nigeria. European Journal of Scientific Research, 23(4): 528- 236.

Ashaolu, E.D \& Adebayo, M.O. 2014. Characterizing Groundwater Level and Flow Pattern in Shallow Overburden Aquifer: a study of Ilara-Mokin and its Environs, Southwestern, Nigeria. Momona Ethiopian Journal of Science, 6(2):55.74.

Azeez, L.O. 1972. Rural Water Supply in the Basement Complex of Western State, Nigeria. Bullettin, IASH, 17(1): 97-110.

Bala, A.E., Eduvie, O.M \& Byami, J. 2011. Borehole Depth and Regolith Aquifer Hydraulic Characteristics of Bedrock Types in Kano area, Northern Nigeria. African Journal of Environmental Science and Technology, 5(3): 228-237. 
Goulden, M., Conway, D \& Persechino, A. 2009. Adaptation to Climate Change in International River Basins in Africa: a review. Hydrological Sciences Journal, 54(5): 805-828.

Huang, Y.P., Kung, W.J \& Lee, C.H. 2011. Estimating Aquifer Transmissivity in a Basin based on Stream Hydrograph Records using an Analytical Approach. Environmental Earth Science, 63:461-468.

Ifabiyi, I.P. 2005. Construction versus Yield of Deep Wells in Regolith Aquifer of Osun River Basin. Water Resources, 16:1-6.

Ifabiyi, I.P. 1999. Predicting Borehole Yield in Precambrian Basement Complex and Sedimentary Rocks in Central western Nigeria. A publication of the department of Geography, University of Ado-ekiti, Nigeria. Review of Growth and Change, 3(1):713.

Ifabiyi, I.P \& Ahmed, Y.A. 2011. Determination of Household water Demand in a Traditional City: Examples from Western axis of Ilorin Nigeria. Asian-African Journal of Econometrics and Economics, 11(2):395-408.

Ifabiyi, I.P \& Ashaolu, E.D. 2013. Analysis of the Impacts of Rainfall Variability on Public Water Supply in Ilorin, Nigeria. Journal of Meteorology and Climate Science, 11(1):18-26.

Kundzewicz, Z.W \& Doll, P., 2009. Will Groundwater Ease Freshwater Stress under Climate Change? Hydrological Sciences Journal, 54(4): 665-675.

Logan, J. (1964). Estimating Transmissivity from Routine Production Tests of Water Wells. Groundwater, 2: 35-37.

Taylor, R.G., Koussis, A.D \& Tindimgaya, C. (2009). Groundwater and Climate in Africa- a review. Hydrological Sciences. 54(4): 655-664.

Wright, E.P. 1992. The Hydrogeology of Crystalline Basement Aquifers in Africa. Geological Society, London, Special Publications, 66: 1-27. 